\title{
Short-term effects of byproduct amendments and lime on physicochemical and microbiological properties of acidic soil from Jiaodong Peninsula of China
}

\section{Yuwen Shen ${ }^{1,2,3^{*}}$ iD Haitao Lin ${ }^{1}$ Xiaozong Song ${ }^{1}$ Ping Liu $^{1}$ Luji Bo ${ }^{1}$ Jianqiu Chen ${ }^{2,3}$ Li Yang $^{1}$ iD}

${ }^{1}$ Shandong Academy of Agricultural Sciences, Institute of Agricultural Resources and Environment, Key Laboratory of Wastes Matrix Utilization, Ministry of Agriculture, Shandong Provincial Engineering Research Center of Environmental Protection Fertilizers, Jinan, 250100, P. R. China.

${ }^{2}$ State Key Laboratory of Nutrition Resources Integrated Utilization, Linyi, P.S., China.

${ }^{3}$ Kingenta Ecological Engineering Group Co., Ltd., Linshu, P.S., China. E-mail: wendy_yws@163.com. "Corresponding author.

ABSTRACT: The influences of byproduct amendments, containing silicon, calcium, magnesium and potassium, on acidic soil quality in Jiaodong Peninsula of China had been studied and compared with that of lime through monitoring physicochemical properties and enzyme activities of acidic soil over a 120-day period. Byproduct amendments $\left(1125,2250,4500\right.$ and $\left.9000 \mathrm{~kg} \mathrm{ha}^{-1}\right)$ and lime $2250 \mathrm{~kg}$ ha-1 was applied in the acidic soil. Results showed that both byproduct amendments and lime significantly increased the pH, EC and enzyme activities of soil. The by-product amendments inhibited microbial biomass carbon and soil respiration. Nevertheless, the lime-treated soil had a much more higher level of $\mathrm{CO}_{2}$ emission than the by-product amendments-treated soil. Compared to the by-product amendmentstreated soil, the lime-treated soil had the higher $\mathrm{pH}$, peroxidase activity, phenol oxidase activity and invertase activity. Therefore, lime might be a better choice over by-product amendments to improve chemical and biological properties of the acidic soil in Jiaodong Peninsula of China. For soils lacking available calcium and magnesium, the mixture of $4500 \mathrm{~kg} \mathrm{ha}^{-1}$ amendments and $2250 \mathrm{~kg}^{-1}$ lime was recommend to treat the soil.

Key words: soil amendments, soil $\mathrm{pH}$, soil respiration, enzyme activity.

Efeitos de alterações de subprodutos e cal em solo ácido da Península de Jiaodong da China

RESUMO: As influências do emprego de subprodutos que contêm silício, cálcio, magnésio e potássio, sobre a qualidade do solo ácido na Península de Jiaodong da China, foram estudadas e comparadas com a da cal através do monitoramento das propriedades fisico-químicas e atividades enzimáticas do solo ácido ao longo de um 120-período do dia. Os resultados mostraram que as alterações dos subprodutos e a cal aumentaram significativamente as atividades de $\mathrm{pH}$, CE e enzimas do solo. As alterações dos subprodutos obviamente inibiram o carbono da biomassa microbiana e a respiração do solo, mas o solo tratado com cal apresentou um maior nível de emissão de CO . Em comparação com as modificações do subproduto, o solo tratado tinha o maior $\mathrm{pH}$, a atividade da peroxidase, a atividade da fenol oxidase e a atividade da invertease. Portanto, o cal pode ser uma escolha melhor em relação às alterações dos subprodutos para melhorar as propriedades químicas e biológicas do solo ácido na Península de Jiaodong da China.

Palavras-chave: emprego de subproduto, cal, solo ácido, $\mathrm{pH}$, atividade.

\section{INTRODUCTION}

Soil acidity could reduce crop yield, pollute water and degrade forest, and further impede global sustainable development (CREGAN \& SCOTT, 1998). Jiaodong Peninsula in China, which is located in the so-called "fruit belt" of North Latitude 36 of the world, has a long tradition of intensive horticultural crop production. In recent decades, its soil acidification is severe according to a preliminary investigation in 2007-2009. The topsoil pH in $60.4 \%$ of the 268 investigated orchard sites was less than 5.5 (LI et al., 2014). Because acid deposition and excessive application of nitrogen fertilizers decrease the soil $\mathrm{pH}$, and fruit trees also take out a great deal of cations from soils in each growing season (TANG et al., 2000), after a continuous period of time, soils may become more and more acidic. Subsequently, soil acidification may increase the bioavailability of metals and worsen their contamination, thus to limit the growth of horticultural crops. Therefore, it is necessary to improve the acidity soil, including increasing soil $\mathrm{pH}$ and ameliorating soil physicochemical properties, of 
orchard at Jiaodong Peninsula in China to optimize the fruit growth and quality.

Traditionally, lime and gypsum have been applied to improve surface acidity of acidic soils. However, their applications have been limited due to their high cost in Jiaodong Peninsula of China and very limited ability to increase the amount of K, P and other nutrient elements (SUN et al., 2000). Recently, scientists turn their attention to industrial byproducts for ameliorating acidic soil (LI et al., 2010), because, except of alkalis, industrial byproducts also contain a large amount of $\mathrm{K}, \mathrm{Ca}, \mathrm{Mg}$ and other nutrient elements (GARRIDO et al., 2003; TRAN et al., 2015). For example, alkaline slag and sugar foam had been used to raise soil $\mathrm{pH}$, precipitate $\mathrm{Al}^{3+}$ and increase concentration of exchangeable $\mathrm{Ca}^{2+}$ and $\mathrm{Mg}^{2+}$ (GARRIDO et al., 2003; LI et al., 2010). In China, alkaline byproducts, a mixture of low-grade phosphate rocks, insoluble potassium-containing rock and coke powder, have been widely used as amendments to improve acidic soils for decades (ZHANG et al., 2015). However, their potential positive and negative impacts on the environment have not been studied.

The amendment was byproduct of nitrocompound fertilizer through calcination of potassium feldspar and limestone at a high temperature. The amendment has a high $\mathrm{pH}$ value with highconcentration of $\mathrm{Ca}, \mathrm{Mg}, \mathrm{K}, \mathrm{Si}$ and $\mathrm{P}$, and trace amount of heavy metals. Therefore, the alkaline byproduct amendment could potentially be used to ameliorate soil acidity and improve soil nutrient levels. Although, there are some reported studies on the effects of the amendments on the chemical and physical properties of acidic soils (ZHANG et al., 2015; CHEN et al., 2015; YU et al., 2015), little attention has been paid to their effects on soil microbial processes and soil enzyme activities. Therefore, in this study, experiments were designed and conducted to investigate the effects of byproduct amendments on the physicochemical properties and microbial activities of acidic soil, which was further compared with that of lime. Specific objectives were (1) to determine both positive and negative impacts of byproduct amendment and lime on the environment in short term, and (2) to determine proper amount of byproduct amendment and lime amendment in acidic soil amelioration. Therefore, two incubation experiments were conducted to investigate the impact of byproduct amendment and lime addition on changes in physicochemical properties of acidic soil and changes in inorganic $\mathrm{N}$ content, soil respiration, microbial biomass and enzyme activities.

\section{MATERIALS AND METHODS}

Lime was from Guoyao Shiji in China. The byproduct amendments, which was a mixture of low-grade phosphate rocks, insoluble potassium containing rocks and coke powder, was from Kingenta Ecological Engineering Group Co. It was crushed within a spinning hammer mill to particle size of $<2 \mathrm{~mm}$ in diameter. $\mathrm{pH}$ value (8.80) and chemical compositions of byproduct amendments were listed in table 1.

\section{Soil samples}

Soil samples were randomly collected from different locations at depth of $0-20 \mathrm{~cm}$ of the orchards in Qixia, Northeast of Jiaodong Peninsula of China. These fresh soil samples were passed through a $2 \mathrm{~mm}$ Nylon sieve before use. Table 2 lists the basic chemical parameters of the studied soil samples. Recently, due to the insufficient input of organic fertilizer and the extensively application of nitrogenbased quick-acting fertilizer, organic matter in some orchards is seriously deficient. At the same time, exchangeable calcium and exchangeable magnesium in soil are also relatively insufficient.

\section{Soil treatment with the byproduct amendments}

One air-dried soil sample (150 g) with or without byproduct amendments was mixed with deionized water in a $200 \mathrm{~mL}$ plastic container to reach $40 \%$ of the soil holding capacity. The container was covered with plastic film with 10 holes to allow gas exchange to maintain moisture. The sample was incubated at $25{ }^{\circ} \mathrm{C}$ for a week to reduce variation in microbial activity. All 144 soil samples were assigned into six groups, including blank samples without byproduct amendments (CK), samples with $0.075 \mathrm{~g}$ (equivalent to approximately $1125 \mathrm{~kg} \mathrm{ha}^{-1}$ amendments distributed in $20 \mathrm{~cm}$ of topsoil at the field) of byproduct amendments

Table 1 - Chemical composition of the amendment.

\begin{tabular}{lrcc}
\hline \multicolumn{2}{c}{----Macro-components---- } & \multicolumn{2}{c}{------Micro-components----- } \\
\hline $\mathrm{C}$ & $12.3 \mathrm{~g} \mathrm{~kg}^{-1}$ & $\mathrm{~F}$ & \multicolumn{1}{c}{$5 \mathrm{~g} \mathrm{~kg}^{-1}$} \\
$\mathrm{P}_{2} \mathrm{O}_{5}$ & $13.4 \mathrm{~g} \mathrm{~kg}^{-1}$ & $\mathrm{H}$ & $950 \mathrm{mg} \mathrm{kg}^{-1}$ \\
$\mathrm{~K}_{2} \mathrm{O}$ & $35.3 \mathrm{~g} \mathrm{~kg}^{-1}$ & $\mathrm{As}$ & $7.77 \mathrm{mg} \mathrm{kg}^{-1}$ \\
$\mathrm{MgO}$ & $34.5 \mathrm{~g} \mathrm{~kg}^{-1}$ & $\mathrm{~Pb}$ & $18.60 \mathrm{mg} \mathrm{kg}^{-1}$ \\
$\mathrm{SiO}$ & $223.8 \mathrm{~g} \mathrm{~kg}^{-1}$ & $\mathrm{Cr}$ & $56.8 \mathrm{mg} \mathrm{kg}^{-1}$ \\
$\mathrm{CaO}$ & $374.3 \mathrm{~g} \mathrm{~kg}^{-1}$ & $\mathrm{Cd}$ & $0.063 \mathrm{mg} \mathrm{kg}^{-1}$ \\
$\mathrm{Fe}_{2} \mathrm{O}_{3}$ & $23.1 \mathrm{~g} \mathrm{~kg}^{-1}$ & $\mathrm{Hg}$ & $0.01 \mathrm{mg} \mathrm{kg}^{-1}$ \\
\hline
\end{tabular}


Table 2 - Chemical parameters of the studied Brown soil.

\begin{tabular}{lccc}
\hline $\mathrm{pH}$ & 6.05 & Exchangeable Ca & $9.53 \mathrm{cmolc} \mathrm{kg}^{-1}$ \\
\hline $\begin{array}{l}\text { Organic } \\
\text { matter }\end{array}$ & $1.36 \%$ & Exchangeable Mg & $2.53 \mathrm{cmolc} \mathrm{kg}^{-1}$ \\
$\mathrm{NH}_{4}{ }^{+}-\mathrm{N}$ & $48.78 \mathrm{mg} \mathrm{kg}^{-1}$ & Exchangeable $\mathrm{Al}$ & $0.14 \mathrm{cmolc} \mathrm{kg}^{-1}$ \\
$\mathrm{NO}_{3}{ }^{-} \mathrm{N}$ & $84.20 \mathrm{mg} \mathrm{kg}^{-1}$ & Base saturation & $68 \%$ \\
\hline
\end{tabular}

(75T), samples with $0.15 \mathrm{~g}$ (i.e. $2250 \mathrm{~kg} \mathrm{ha}^{-1}$ ) of byproduct amendments (150T), samples with $0.3 \mathrm{~g}$ (i.e. $4500 \mathrm{~kg} \mathrm{ha}^{-1}$ ) of byproduct amendments (300T), samples with $0.6 \mathrm{~g}$ (i.e. $9000 \mathrm{~kg} \mathrm{ha}^{-1}$ ) of byproduct amendments $(600 \mathrm{~T})$ and samples with $0.15 \mathrm{~g}$ (i.e. $\left.2250 \mathrm{~kg} \mathrm{ha}^{-1}\right)$ of lime $(150 \mathrm{CaO})$.

\section{Soil incubation experiments}

Soil moisture content was maintained at $60 \%$ of the soil holding capacity during the experiment through injecting a certain amount of water every four days. Two sets of incubation studies were conducted. One set was used to study changes in physiochemical properties and the other set was used to study soil respiration. Generally, during soil samples were incubated at $25{ }^{\circ} \mathrm{C}$, their enzyme activities, mineral nitrogen, microbial biomass, $\mathrm{pH}$ and electronic conductivity (EC) were measured on Day $0,1,3,7,15,30,60$ and 120 with 4 replicates at each time point. A total of 24 soil samples in the four groups were incubated at $25{ }^{\circ} \mathrm{C}$ and $\mathrm{CO}_{2}$ emission from each sample was measured at day $0,1,2,5$, $10,30,60$ and 120 of incubation with 4 replicates at each time point.

\section{Analysis methods}

Characterization of soil physicochemical properties

After the fresh incubated soil sample was mixed with water at 1:2.5 ratio (w/v, soil to water) and shaken for an hour, its $\mathrm{pH}$ and EC were determined on a pH meter (METTLER TOLEDO S210-K pH meter, USA) and an electronic conductivity meter (DDSJ308A, Shanghai Leici, China), respectively.

\section{Analysis on soil enzyme activities}

Enzyme activities of soil sample were determined with a 144-well microplate approach as reported (ŠNAJDR et al., 2008). Activities of phenol oxidase were measured with pyrogallic acid as the reductive substrate (PERUCCI et al., 2000; VEPSALAINEN et al., 2001). Optical density was measured at $525 \mathrm{~nm}$.
Peroxidase activities were measured with 3,3',5,5'-tetra methyl benzidine (TMB) as the reductive substrate (JOHNSEN \& JACOBSEN , 2008). Optical density was measured at $450 \mathrm{~nm}$.

Soil enzyme activity is expressed as $\mu \mathrm{mol}$ of product per hour per $\mathrm{g}$ of soil. After the soil was incubated with $15 \mathrm{~mL}$ of $8 \%$ sucrose solution and $5 \mathrm{~mL}$ of phosphate buffer $\left(\mathrm{pH} \mathrm{5.5)}\right.$ at $37^{\circ} \mathrm{C}$ for $24 \mathrm{~h}$, invertase activity (mg glucose $\mathrm{g}^{-1} 24 \mathrm{~h}^{-1}$ ) was measured with glucose as the reducing sugar through colorimetry at $510 \mathrm{~nm}$ with 3,5-dinitrosalicylic acid (GUAN et al., 1986).

\section{Analysis on microbial biomass}

Microbial biomass was determined with chloroform fumigation extraction method (VANCE et al., 1987). Typically, after 24 hours of fumigation with chloroform, soil samples with and without fumigation were extracted with $0.5 \mathrm{~mol} \mathrm{~L}^{-1} \mathrm{~K}_{2} \mathrm{SO}_{4}$ solution at 1:2 soil: solution ratio. The microbial biomass $\mathrm{C}(\mathrm{MBC})$ and microbial biomass $\mathrm{N}(\mathrm{MBN})$ were determined on an organic carbon analyzer (Vario TOC, ELEMENTAR, Germany) through ninhydrin reaction as reported (JOERGENSEN \& BROOKES, 1990).

\section{Analysis on soil respiration}

Soil respiration was determined with gas chromatography (Agilent 7890A, USA). Before and after $\mathrm{CO}_{2}$ was trapped in the tightly rubber-plugged container for 24 hours at $25^{\circ} \mathrm{C}, 40 \mathrm{~mL}$ of gas sample was collected with a syringe and injected into the gas analyzer. Difference between the final $\mathrm{CO}_{2}$ content and the initial $\mathrm{CO}_{2}$ content was calculated as the $\mathrm{CO}_{2}$ emission.

\section{Statistical analysis}

Ducan test was applied to compare the difference among different treatments. A $p$ value less than 0.05 was considered as a statistical significance. Kinetic modeling of the experiment data was performed with Origin Pro 8.0.

\section{RESULTS AND DISCUSSION}

Effect of amendments on soil physicochemical properties

The $\mathrm{pH}$ of the soil solution is very important to determine the chemical environment of plants (BOLAN et al., 2003) because any component of the soil or of its biological inhabitants is very sensitive to soil $\mathrm{pH}$. The $\mathrm{pH}$ of soil without amendments is 6.05. As shown in Figure 1a, compared to $\mathrm{pH}$ of 
soil treated with $\mathrm{CK}$, the $\mathrm{pH}$ of soil was increased with the addition of byproduct amendments or the increase of incubation time, and the maximum value was observed in soil sample treated with $0.15 \mathrm{~g}$ of lime $(150 \mathrm{CaO})$. However, in the late stage of incubation period, the $\mathrm{pH}$ of soils with all amendments treatments was reduced significantly. The $\mathrm{pH}$ of soil with maximum of byproduct amendments (600T) increased from 6.05 to 6.69, but decreased to 6.32 after 120 days incubation. The $\mathrm{pH}$ of soil sample $150 \mathrm{CaO}$ increased sharply to 7.82 and significantly dropped to 6.53. Results indicated that both amendments could increase soil $\mathrm{pH}$ and the effect of lime was much larger. Biochemical processes associated with soil $\mathrm{pH}$ change are mainly as follows: the release of alkalinity, ammonification of organic nitrogen, nitrification of mineralized nitrogen, and cation-exchange reactions between cations and exchangeable acidity (MOKOLOBATE \& HAYNES, 2002; WANG et al., 2009; ZHAO \& XING, 2009). The alkali neutralization capacity could be the predominant factor for soil $\mathrm{pH}$ change, especially the soil with lime. The byproduct amendments contained large amount of cations, such as $\mathrm{Ca}^{2+}, \mathrm{Mg}^{2+}$ and $\mathrm{K}^{+}$, with anions, such as $\mathrm{SO}_{4}^{2-}, \mathrm{F}^{-}$ and $\mathrm{SiO}_{4}^{2-}$. The cations can induce the release of $\mathrm{H}^{+}$and $\mathrm{Al}^{3+}$ and these anions can release $\mathrm{OH}^{-}$due to the ligand exchange. Therefore, the soil $\mathrm{pH}$ with byproduct amendment was increased slightly until day 7 and decreased at day 15 .

As shown in figure $1 \mathrm{~b}$, compared to $\mathrm{CK}$ treatment, byproduct amendments increased both $\mathrm{pH}$ and EC of soil, which might have negative effects on soil structural stability, bulk density and permeability (TEJADA \& GONZALEZ, 2005). Application of amendments increased the $\mathrm{pH}$ of soils and the variation tendency of soil EC was consistent with $\mathrm{pH}$. Soil EC was significantly influenced by applied soil amendments. The maximum values were observed in the soil sample $150 \mathrm{CaO}$ at the beginning of the experiment. However, soil EC values of $150 \mathrm{CaO}, 75 \mathrm{~T}$ and $150 \mathrm{~T}$ dropped quickly after 60 days of incubation.

\section{Effect of amendments on microbial biomass}

Microbial biomass carbon (MBC) of soils treated with byproduct amendments or lime was increased due to the increase of EC, compared to that of control soils without amendment. As shown in figure $2 \mathrm{a}$, the $150 \mathrm{CaO}$ sample had the maximum content of MBC. And the MBC decreased along the time, indicating that the concentration of dissolved ions was increased during incubation (SARIG \& STEINBERGER, 1994).

Similarly, both byproduct amendments and lime significantly influenced microbial biomass nitrogen (MBN) of soil samples; although, effects of byproduct amendments were larger than that of lime (Figure 2b). And soil samples 150T and 300T had the highest amount of MBN than others.

\section{Soil respiration}

Soil microbial respiration is a direct indicator of microbial activity and indirect indicator of the availability of organic materials (TEJADA et al., 2006). And the most common method to evaluate microbial activity of soil is based on the measurement of $\mathrm{CO}_{2}$ evolved from soil as a consequence of
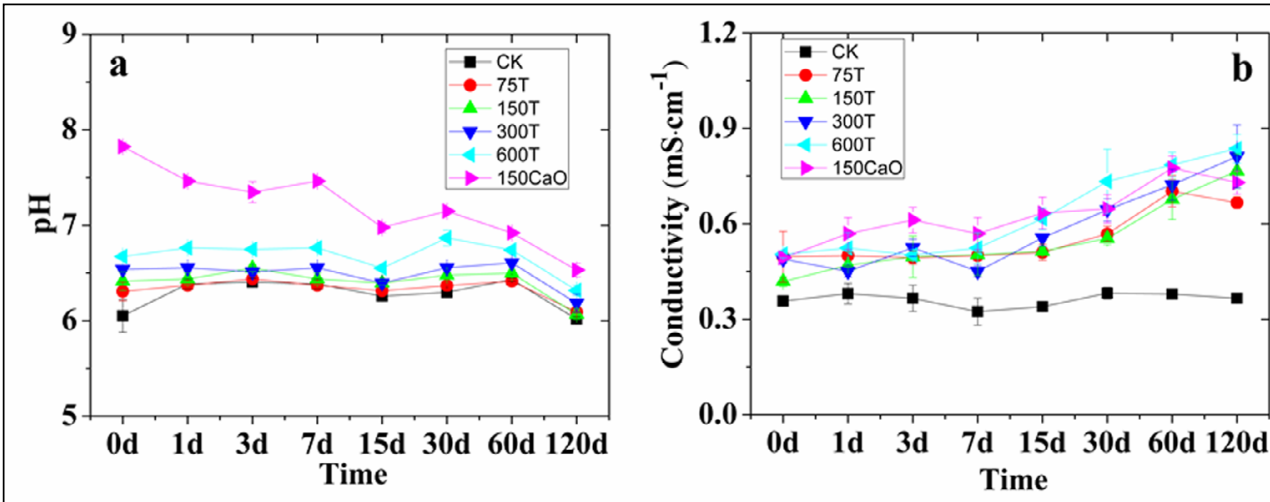

Figure 1 - Effects of the byproduct amendments with increasing levels of $\mathrm{CaO}$ on (a) soil pH, (b) soil electronic conductivity during the 120 days of incubation. Error bars are the standard deviation of four independent experiments, $n=4$. 

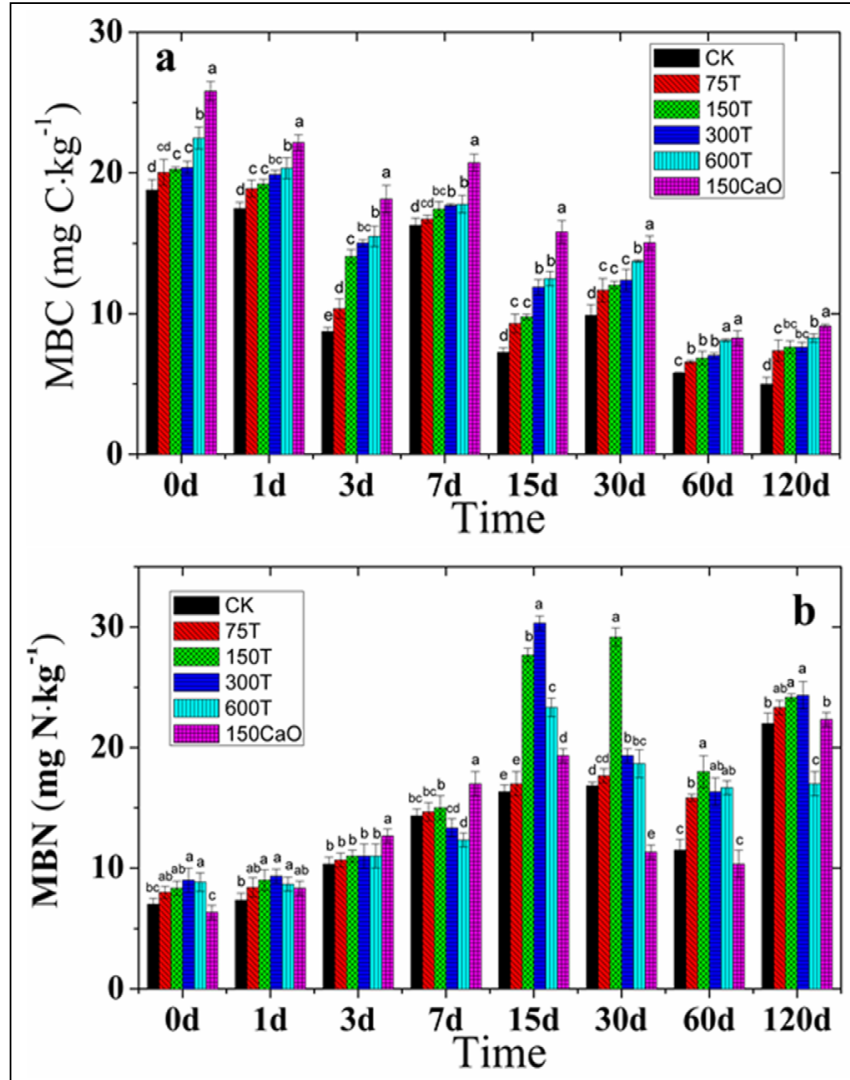

Figure 2 - Effects of byproduct amendments with increasing levels of $\mathrm{CaO}$ (a) on microbial biomass $\mathrm{C}$ (MBC) and (b) microbial biomass $\mathrm{N}$ (MBN) of soil during the 120 days of incubation. All treatments were conducted at $25{ }^{\circ} \mathrm{C}$ for 120 days. Different small letters indicate significant differences of mean value at $\mathrm{P}<0.05$. Error bars are the standard deviation of 4 independent experiments, $\mathrm{n}=4$.

microbial respiration (SÁNCHEZ-MONEDERO et al., 2008). The $\mathrm{CO}_{2}$ emission of all soil samples decreased gradually during the whole incubation period (Figure 3). Because $\mathrm{CO}_{2}$ emission of soils was relatively low in alkaline amendments with high EC and high pH (KOWALENKO et al., 1978; RAO \& PATHAK , 1996), compared soil sample treated with $\mathrm{CK}$, soil sample treated with more byproduct amendments had less $\mathrm{CO}_{2}$ emission. However, the soil $150 \mathrm{CaO}$ always had the largest amount of MBC and the maximum $\mathrm{CO}_{2}$ emission during the 120-day experiment, probably because $\mathrm{CaO}$ could react with water and dry the soil, which could accelerate the release of $\mathrm{CO}_{2}$.

\section{Soil enzyme activities}

Enzyme activities are sensitive indicators of ecological stress. For example, peroxidase (POD), an oxidoreductase, can reduce oxygen to $\mathrm{H}_{2} \mathrm{O}_{2}$ while oxidizing hydroxyls to carbonyls. In the soil, the generated soil peroxidase accelerates the degradation of humic materials and thus leads to more $\mathrm{CO}_{2}$ release (DEC et al., 2003). And phenol oxidase (SPPO) can catalyze the oxidation of aromatic materials such as humic acids (FLOCH et al., 2007). Although, activities of these soil oxidative enzymes are independent of soil carbon content, they are sensitive to soil $\mathrm{pH}$ and other factors (SINSABAUGH et al., 2008; FLOCH et al., 2009).

As shown in figure $4 \mathrm{a}$, compared soil sample treated with $\mathrm{CK}$, soil sample $150 \mathrm{CaO}$ always had the highest peroxidase activity and $\mathrm{CO}_{2}$ emission over the 30-day incubation period compared to other sample treated with byproduct amendments. And there was no significant difference among effects of byproduct amendments amount on the peroxidase activity. 


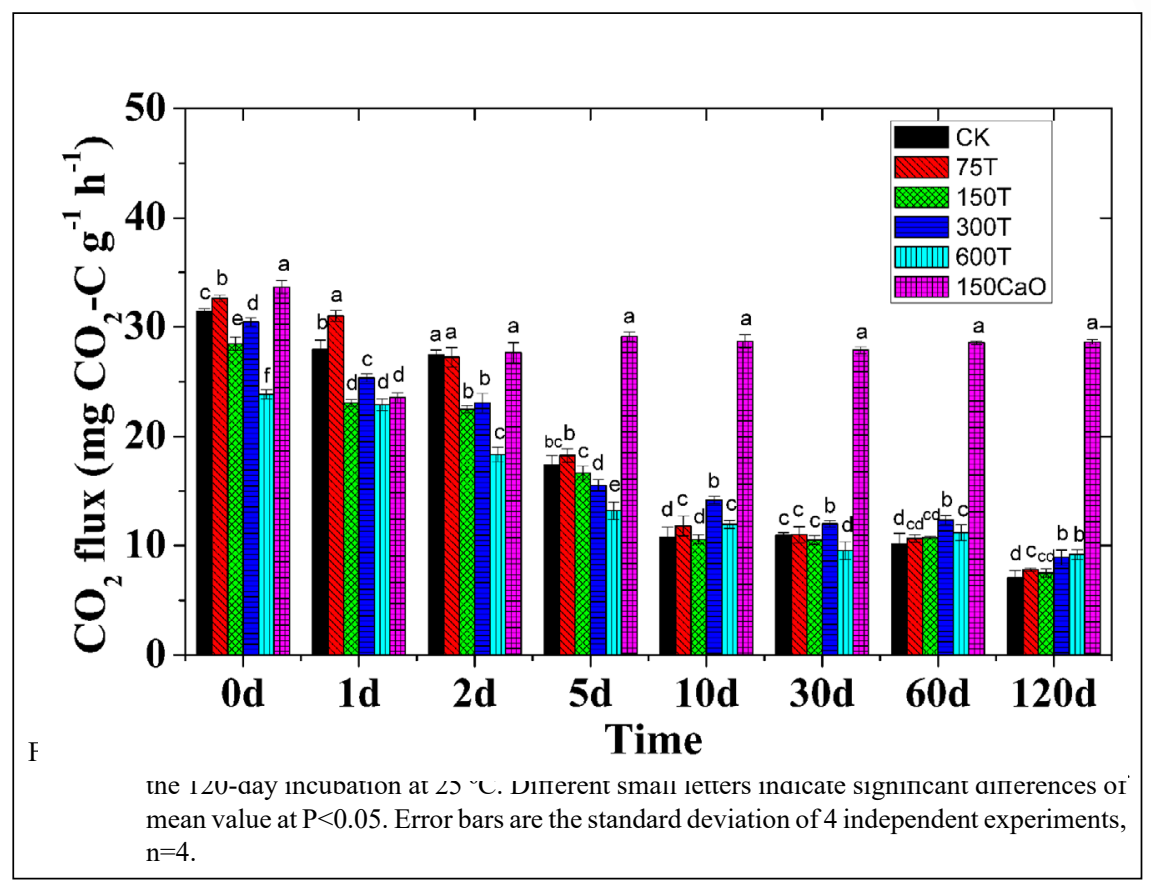

As shown in figure $4 \mathrm{~b}$, the phenol oxidase (SPPO) activities of all samples were increased within 30 days of incubation and were then decreased, and sample $150 \mathrm{CaO}$ also always had the highest SPPO activity over the 30-day incubation period at $25^{\circ} \mathrm{C}$ (Figure $4 \mathrm{~b}$ ), which was in accordance with the tendency of soil $\mathrm{pH}$. These results further proved that phenol oxidase activity and stability of soil were correlated positively with its $\mathrm{pH}$ (SINSABAUGH, 2010).

Since the main energy of soil microorganisms is from sucrose and free simple sugars that should be hydrolyzed and broken down with the enzyme invertase (S-SC) (FRANKENBERGER \& JOHANSON, 1983), invertase is more efficient than other enzymes to reflect soil fertility and biological activity. As shown in figure $4 \mathrm{c}$, the soil S-SC activity was significantly increased with all amendments during the incubation period, and sample $150 \mathrm{CaO}$ always showed the highest S-SC activity compared to other samples over the 30-day incubation period at 25 ${ }^{\circ} \mathrm{C}$. Additionally, the S-SC activity was increased with the increase of byproduct amendments. These results were in accordance with the tendency of soil $\mathrm{pH}$ in all soil samples, which further proved the S-SC activity and stability of soil were influenced significantly by its $\mathrm{pH}$ and ionic strength (GUAN, 1986; GIANFREDA \& BOLLAG, 1996;
ACOSTA-MARTINEZ et al., 2000; EKENLER \& TABATABAI , 2003).

\section{CONCLUSION}

Both byproduct amendments and lime significantly increased $\mathrm{pH}, \mathrm{EC}$ and enzyme activities of the soil. The byproduct amendments inhibited microbial biomass carbon and soil respiration, but the lime-treated soil had a much more higher level of $\mathrm{CO}_{2}$ emission than the byproduct amendmentstreated soil. The soil treated with lime had the highest levels of $\mathrm{pH}$, peroxidase activity, phenol oxidase activity and invertase activity among all soil samples. Therefore, lime might be a better short-term choice over byproduct amendments to improve the chemical and biological properties of the acidic soil in Jiaodong Peninsula of China. Byproduct amendments not only increased soil $\mathrm{pH}$ but also contained plentiful cations and anions, such as $\mathrm{Ca}, \mathrm{Mg}$, Si and P. Plentiful $\mathrm{Ca}$ and $\mathrm{Mg}$ in the byproduct can alleviate $\mathrm{Al}$ and $\mathrm{Mn}$ toxicity to plants and microorganisms by competitive adsorption. Consequently, the use of byproduct as amendments for acidic soil has some great potential as the traditional used lime in short time; although, its advantages are not dominant. Therefore, soil treated with $4500 \mathrm{~kg} \mathrm{ha}^{-1}$ byproduct amendments (300T) mixed with $2250 \mathrm{~kg} \mathrm{ha}^{-1}$ lime $(150 \mathrm{CaO})$ 


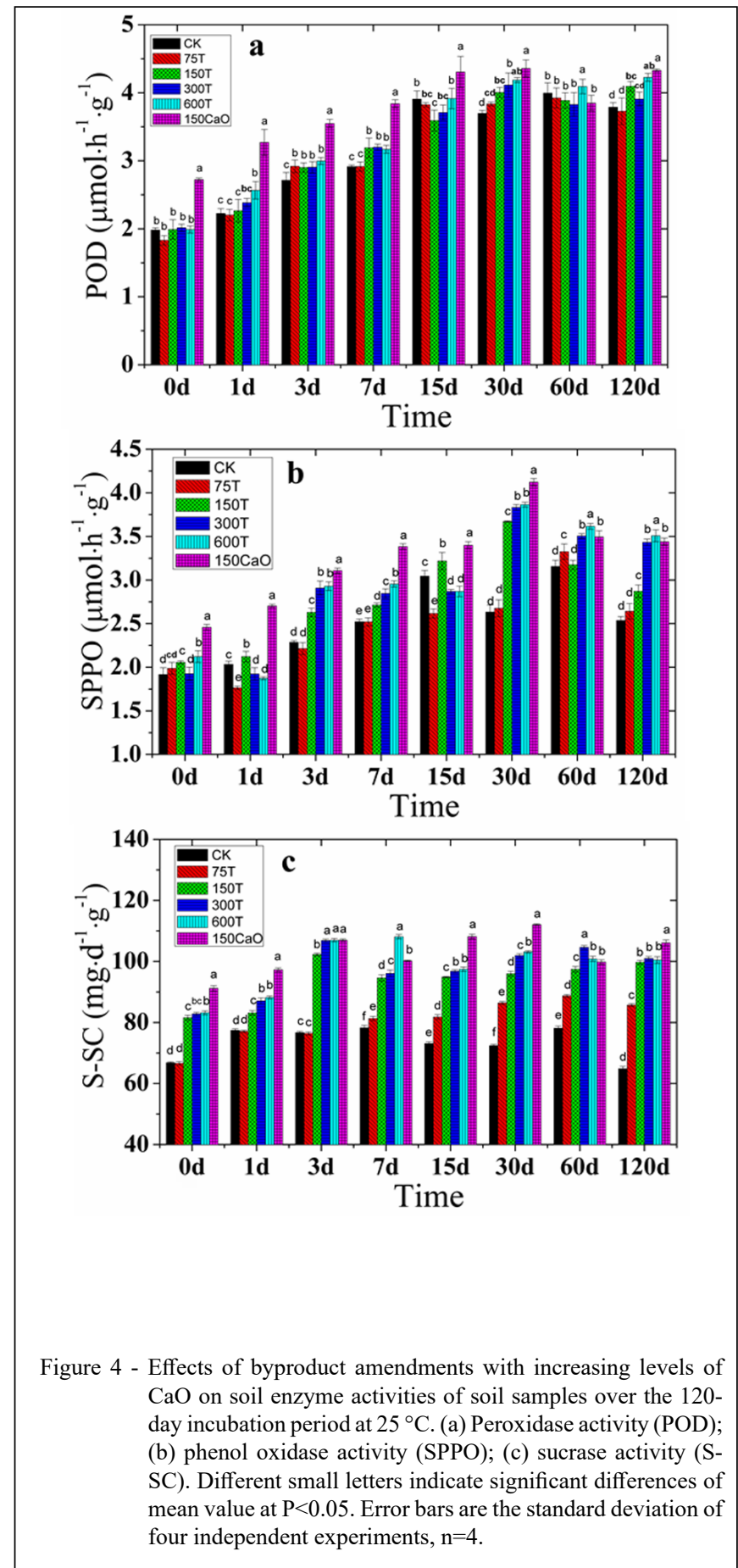

was recommend applied in acidic soil of Jiaodong Peninsula of China.

\section{ACKNOWLEDGEMENTS}

This work was supported financially by the National Key Research and Development Plan (2017YFD0800602); the
Natural Science Foundation of Shandong Province(ZR2016BQ30); National CF Engineering Research Center Program, 12th FiveYear Plan National Science and technology support program (2011BAD11B02); Key R\&D Program of Shandong Province (2017CXGC0304); the Innovation project of agricultural science and technology in Shandong Academy of Agricultural Sciences (CXGC2016A07); The Natural Science Foundation of Shandong Province (ZR2016DB28) and The Youth Scientific Research

Ciência Rural, v.49, n.6, 2019. 
Foundation of Shandong Academy of Agricultural Sciences (2016YQN40).

\section{DECLARATION OF CONFLICT OF INTERESTS}

The authors declare no conflict of interest. The founding sponsors had no role in the design of the study; in the collection, analyses, or interpretation of data; in the writing of the manuscript, and in the decision to publish the results.

\section{AUTHORS' CONTRIBUTIONS}

All authors contributed equally for the conception and writing of the manuscript. All authors critically revised the manuscript and approved of the final version.

\section{REFERENCES}

ACOSTA-MARTINEZ, V.; TABATABAI, M.A. Enzyme activities in a limed agricultural soil. Biology \& Fertility of Soils, v.31, p.85-91. 2000. Available from: <https://doi.org/10.1007/s003740050628>. Accessed: Feb. 09, 2018. doi: 10.1007/s003740050628.

BOLAN, N.S. et al. Soil acidification and liming interactions with nutrient and heavy metal transformation and bioavailability. Advances in Agronomy, v.78, p.215-272. 2003. Available from: $<$ https://doi.org/10.1016/S0065-2113(02)78006-1>. Accessed: Feb. 09, 2018. doi: 10.1016/S0065-2113(02)78006-1.

CHEN, K. et al. Impacts of different fertilizers/amendments on rice yield and nutrient uptake and soil properties in the waterlogged paddy field. Journal of Plant Nutrition and Fertilizer, v.03, p.773-781. 2015. Available from: <http://www.plantnutrifert.org/ EN/10.11674/zwyf.2015.0325>. Accessed: Feb. 09, 2018. doi: 10.11674/zwyf.2015.0325.

CREGAN, P.; SCOTT, B. Soil acidification-An agricultural and environmental problem. In: PRATLEY, J.E.; ROBERTSON, A.I. Agriculture and the Environmental Imperative. CSIRO Publishing: Melbourne, 1998. p.98-128.

DEC, J. et al. Release of substituents from phenolic compounds during oxidative coupling reactions. Chemosphere, v.52, p.549 556. 2003. Available from: <https://doi.org/10.1016/S00456535(03)00236-4>. Accessed: Feb. 09, 2018. doi: 10.1016/S00456535(03)00236-4.

EKENLER, M.; TABATABAI, M.A. Effects of liming and tillage systems onmicrobial biomass and glycosidases in soils. Biology $\boldsymbol{\&}$ Fertility of Soils, v.39, p.51-61. 2003. Available from: $<$ http://doi. org/10.1007/s00374-003-0664-8>. Accessed: Feb. 09, 2018. doi: 10.1007/s00374-003-0664-8.

FLOCH, C. et al. ABTS assay of phenol oxidase activity in soil. Journal of Microbiological Methods, v.71, p.319-324. 2007. Available from: <https://doi.org/10.1016/j.mimet.2007.09.020>. Accessed: Feb. 09, 2018. doi: 10.1016/j.mimet.2007.09.020.

FLOCH, C. et al. Enzyme activities in apple orchard agroecosystems: how are they affected by management strategy and soil properties. Soil Biology \& Biochemistry, v.41, p.61-68. 2009. Available from: <https://doi.org/10.1016/j.soilbio.2008.09.018>. Accessed: Feb. 09, 2018. doi: 10.1016/j.soilbio.2008.09.018.
FRANKENBERGER, J.R.; JOHANSON, J.B. Method of measuring invertase activity in soils. Plant Soil, v.74, p.301-311. 1983. Available from: <https://link.springer.com/ article/10.1007\%2FBF02181348>. Accessed: Feb. 09, 2018. doi: $10.1007 / \mathrm{bf} 02181348$.

GARRIDO, F. et al. Evaluation of industrial byproducts as soil acidity amendment: chemical and mineralogical implications. European Journal of Soil Science, v.54, p.411-422. 2003. Available from: $<$ https://doi.org/10.1046/j.1365-2389.2003.00522.x>. Accessed: Feb. 09, 2018. doi: 10.1046/j.1365-2389.2003.00522.x.

GIANFREDA, L.; BOLLAG, J.M. Influence of natural and anthropogenic factors on enzyme activity in soil. In: STOTZKY, G.; BOLLAG, J.M. Soil biochemistry. Marcel Dekker: New York, 1996. p.123-194.

GUAN, S.Y. Soil Enzymology and Research Method. Agricultural Press: Beijing, 1986. (in Chinese).

JOERGENSEN, R.G.; BROOKES, P.C. Ninhydrin-reactive nitrogen measurements of microbial biomass in $0.5 \mathrm{M} \mathrm{K}_{2} \mathrm{SO}_{4}$ soil extracts. Soil Biology \& Biochemistry, v.22, p.1023-1027. 1990. Available from: <https://doi.org/10.1016/0038-0717(90)90027-W>. Accessed: Feb. 09, 2018. doi: 10.1016/0038-0717(90)90027-W.

JOHNSEN, A.R.; JACOBSEN, O.S. A quick and sensitive method for the quantification of peroxidase activity of organic surface soil from forests. Soil Biology \& Biochemistry, v.40, p.814-821. 2008. Available from: <https://doi.org/10.1016/j.soilbio.2007.10.017>. Accessed: Feb. 09, 2018. doi: 10.1016/j.soilbio.2007.10.017.

KOWALENKO, C.G. et al. Effect of moisture content, temperature and nitrogen fertilization on carbon dioxide evolution from field soils. Soil Biology \& Biochemistry, v.10, p.417-423. 1978. Available from: <https://doi.org/10.1016/0038-0717(78)900688>. Accessed: Feb. 09, 2018. doi: 10.1016/0038-0717(78)90068-8.

LI, J.Y. et al. Potential of industrial byproducts in ameliorating acidity and aluminum toxicity of soils under tea plantation. Pedosphere, v.20, p.645-654. 2010. Available from: $<$ https://doi. org/10.1016/S1002-0160(10)60054-9>. Accessed: Feb. 09, 2018. doi: 10.1016/S1002-0160(10)60054-9.

LI, L. et al. Soil acidification increases metal extractability and bioavailability in old orchard soils of Northeast Jiaodong Peninsula in China. Environmental Pollution, v.188, p.144-152. 2014. Available from: <https://doi.org/10.1016/j.envpol.2014.02.003>. Accessed: Feb. 09, 2018. doi: 10.1016/j.envpol.2014.02.003.

MOKOLOBATE, M.S.; HAYNES, R.J. Increases in pH and soluble salts influence the effect that additions of organic residues have on concentrations of exchangeable and soil solution aluminum. European Journal of Soil Science, v.53, p.481-489. 2002. Available from: <https://doi:10.1046/j.1365-2389.2002.00465.x>. Accessed: May, 09, 2018. doi: 10.1046/j.1365-2389.2002.00465.x.

PERUCCI, P. et al. An improved method to evaluate the o-diphenol oxidase activity of soil. Soil Biology \& Biochemistry, v.32, p.1927-1933. 2000. Available from: <https://doi.org/10.1016/ S0038-0717(00)00168-1>. Accessed: Feb. 09, 2018. doi: 10.1016/ S0038-0717(00)00168-1.

RAO, D.L.N.; PATHAK, H. Ameliorative influence of organic matter on biological activity of salt affected soils. Arid Soil Research \& Rehabilitation, v.10, p.311-319. 1996. Available 
from: <https://doi.org/10.1080/15324989609381446>. Accessed: Feb. 09, 2018. doi: 10.1080/15324989609381446.

SÁNCHEZ-MONEDERO, M.A. et al. Fluorescein diacetate hydrolysis, respiration and microbial biomass in freshly amended soils. Biology \& Fertility of Soils, v.44, p.885-890. 2008. Available from: <http://doi.org/0.1007/s00374-007-0263-1>. Accessed: Feb. 09, 2018. doi: 0.1007/s00374-007-0263-1.

SARIG, S.; STEINBERGER, Y. Microbial biomass response to seasonal fluctuation in soil salinity under the canopy of desert halophytes. Soil Biology \& Biochemistry, v.26, p.14051408. 1994. Available from: <https://doi.org/10.1016/00380717(94)90224-0>. Accessed: Feb. 09, 2018. doi: 10.1016/00380717(94)90224-0.

SINSABAUGH, R.L. et al. Stoichiometry of soil enzyme activity at global scale. Ecology Letters, v.11, p.1252-1254. 2008. Available from: $<$ http://doi.org/10.1111/j.1461-0248.2008.01245.x>. Accessed: Feb. 09, 2018. doi: 10.1111/j.1461-0248.2008.01245.x.

SINSABAUGH, R.L. Phenol oxidase, peroxidase and organic matter dynamics of soil. Soil Biology and Biochemistry, v.42, p.391-404. 2010. Available from: <https://doi.org/10.1016/j. soilbio.2009.10.014>. Accessed: Feb. 09, 2018. doi: 10.1016/j. soilbio.2009.10.014

ŠNAJDR, J. et al. Spatial variability of enzyme activities and microbial biomass in the upper layers of Quercus petraea forest soil. Soil Biology \& Biochemistry, v.40, p.2068-2075. 2008. Available from: <https://doi.org/10.1016/j.soilbio.2008.01.015>. Accessed: Feb. 09, 2018. doi: 10.1016/j.soilbio.2008.01.015.

SUN, B. et al. Effect of slaked lime and gypsum on acidity alleviation and nutrient leaching in an acid soil from Southern China. Nutrient Cycling In Agroecosystems, v.57, p.215-223. 2000. Available from: < http://doi.org/10.1023/A:1009870308097>. Accessed: Feb. 09, 2018. doi: 10.1023/A:1009870308097.

TANG, C. et al. Understanding subsoil acidification: effect of nitrogen transformation and nitrate leaching. Australian Journal of Soil Research, v.38, p.837-849. 2000. Available from: <http:// doi.org/10.1071/SR99109>. Accessed: Feb. 09, 2018. doi: 10.1071/SR99109.

TEJADA, M. et al. Organic amendment based on fresh and composted beet vinasse: influence on soil properties and wheat yield. Soil Science Society of America Journal, v.70, p.900-908. 2006. Available from: $<$ https://dl.sciencesocieties.org/publications/ sssaj/abstracts/70/3/900>. Accessed: Feb. 09, 2018. doi: 10.2136/ sssaj2005.0271.

TEJADA, M.; GONZALEZ, J.L. Beet vinasse applied to wheat under dryland conditions affects soil properties and yield. European Journal of Agronomy, v.23, p.336-347. 2005. Available from: <https://doi.org/10.1016/j.eja.2005.02.005>. Accessed: Feb. 09, 2018. doi: 10.1016/j.eja.2005.02.005.

TRAN, C.K.T.; ROSE, M.T. Lignite amendment has limited impacts on soil microbial communities and mineral nitrogen availability. Applied Soil Ecology, v.95, p.140-150. 2015. Available from: <https://doi.org/10.1016/j.apsoil.2015.06.020>. Accessed: Feb. 09, 2018. doi: 10.1016/j.apsoil.2015.06.020.

VANCE, E.D. et al. An extraction method for measuring soil microbial biomass C. Soil Biology \& Biochemistry, v.19, p.703-707. 1987. Available from: <https://doi.org/10.1016/0038-0717(87)90052-6>. Accessed: Feb. 09, 2018. doi: 10.1016/0038-0717(87)90052-6.

VEPSALAINEN, M. et al. Application of soil enzyme activity test kit in a field experiment. Soil Biology \& Biochemistry, v.33, p.1665-1672. 2001. Available from: $<$ https://doi.org/10.1016/S0038-0717(01)000876>. Accessed: Feb. 09, 2018. doi: 10.1016/S0038-0717(01)00087-6.

WANG, N. et al. Use of agricultural byproducts to study the $\mathrm{pH}$ effects in an acid tea garden soil. Soil Use and Management, v.25, p.128-132. 2009. Available from: <https://doi:10.11 11/j.1475-2743.2009.00203.x>. Accessed: May, 09, 2018. doi:10.1111/j.1475-2743.2009.00203.x.

YU, X. et al. Amelioration effects of the application of calcium peroxide and silicon calcium fertilizer in gleyed paddy fields. Journal of Plant Nutrition and Fertilizer, v.21, p.138-146. 2015. Available from: <http://www.plantnutrifert.org/EN/Y2015/V21/ I1/138>. Accessed: Feb. 09, 2018. doi: 10.11674/zwyf.2015.0115.

ZHANG, J. et al. Effects of calcium fertilizer on yield, quality and related enzyme activities of peanut in acidic soil. Chinese Journal of Plant Ecology, v.11, p.1101-1109. 2015. Available from: $<$ http://www.plant-ecology.com/CN/10.17521/cjpe.2015.0107>. Accessed: Feb. 09, 2018. doi: 10.17521/cjpe.2015.0107.

ZHAO, X.; XING, G.X. Variation in the relationship between nitrification and acidification of subtropical soils as affected by the addition of urea or ammonium sulfate. Soil Biology and Biochemistry, v.41, p.2584-2587. 2009. Available from: <https:// doi:10.1016/j. soilbio.2009.08.022>. Accessed: May, 09, 2018. doi:10.1016/j. soilbio.2009.08.022. 